ROCHA, Ana Luiza Carvalho; ECKERT, Cornelia. Antropologia da e na cidade: interpretações sobre as formas da vida urbana. Porto Alegre: Marcavisual, 2013. $296 \mathrm{p}$.

\title{
Tania Dauster
}

\section{Pontifícia Universidade Católica do Rio de Janeiro - Brasil}

Antropologia da e na cidade: interpretações sobre as formas da vida urbana, das autoras Ana Luiza Rocha e Cornelia Eckert, expressa um percurso de investigação e uma linhagem que tem como fonte a antropologia urbana em inter-relações com a antropologia da imagem.

O livro é um feixe de oito artigos anteriormente publicados em periódicos científicos, oriundos de estudos antropológicos e práticas etnográficas em cidades brasileiras, com foco privilegiado em Porto Alegre. Trata-se de uma obra dedicada in memoriam ao antropólogo Gilberto Velho, falecido em 2012. A produção reunida neste livro é, nas palavras das autoras, "relacionada à linha de pesquisa fundada no Brasil pelo professor Gilberto Velho” (p. 10). De forma análoga, as pesquisadoras declaram filiar-se a uma "comunidade interpretativa, da qual participam antropólogos brasileiros como Eunice Durham, Ruth Cardoso e seus orientados, Ruben Oliven e seus orientados, entre tantos outros” (p. 9).

Este livro encerra e expressa vários significados. Como legado inspirado em Gilberto Velho, aqui perduram suas lições de antropologia urbana, inventam-se outras, pois o entrelaçamento com a antropologia da imagem representa uma feição inovadora e atual, característica da identidade e do modo de vida acadêmico e investigativo das etnógrafas. A obra espelha, segundo os termos de Gilberto Velho (1994), as relações entre carreira, memória e projeto nos trajetos das pesquisadoras. No caso em pauta, o termo memória, por exemplo, é tanto um conceito com o qual as autoras lidam como o cerne do próprio livro. Isso se explica, tendo em vista que o mesmo contém um acervo de trabalhos que fixam as trajetórias das autoras, mostrando seus métodos de estruturação do conhecimento. Nele encontram-se, também, narrativas sobre 
as formas de convivência urbanas a partir de fotos, "uma escrita de imagens", eu diria, uma construção da memória da cidade porto-alegrense. Ademais, de maneira densa e detalhada, são narrados os caminhos pelos quais a antropologia urbana desenrolou-se no Brasil.

As autoras são intérpretes do urbano a partir do ponto de vista e nos termos dos moradores e de suas imagens captadas nas fotos. Nas reconstruções que são feitas dos dados etnográficos, as pesquisadoras e discípulos "estranham o familiar” (Velho, 1978) e vão expondo aos leitores histórias de Porto Alegre e de seus habitantes, que pertencem a diversas gerações e camadas sociais. Eles são personagens e protagonistas, cujas versões de acontecimentos cotidianos se fazem memória enquanto construção social.

Este livro, uma obra de antropologia urbana, uma antropologia da imagem/paisagem e uma antropologia da memória, transcende seu próprio conteúdo e constitui-se como "um objeto-memória” pelas razões anteriormente expostas. São desveladas práticas e representações, continuidades e rupturas e formas de interpretar o urbano, seja teoricamente falando ou através dos métodos de pesquisa etnográficos usados.

Ana Luiza Carvalho da Rocha e Cornelia Eckert com maestria interpretam, instituem e constroem memória ao ultrapassarem as margens da antropologia e transitarem por outras faixas disciplinares. Dialogam com autores em distintos campos do conhecimento. Bachelard lhes dá o alimento filosófico para elaborar a categoria tempo e adotar epistemologicamente a perspectiva da duração. Um ponto alto, entre outros, de suas representações e práticas reside na discussão teórica da categoria paisagem, que tem na filosofia de Simmel um manancial inspirador, assim como abre as veredas para a sua operacionalização no encontro etnográfico.

Tentarei, a seguir, levantar alguns aspectos significativos de cada capítulo, sem a pretensão de esgotá-los.

No primeiro, intitulado "Nas trilhas de uma antropologia da e na cidade no Brasil”, encontram-se as bases da disciplina fora do Brasil na herança da Escola de Chicago, na marca da sociologia de Simmel e na influência da Escola de Manchester com especial atenção à fluidez entre as fronteiras simbólicas e nos usos de redes sociais como método investigativo.

Gilberto Freyre é lembrado pelo exame que faz da noção de cidade, a partir da cena recifense. Eunice Durham e Ruth Cardoso focam a cidade como locus de pesquisa e desenvolvem os usos da etnografia com essa finalidade.

Horizontes Antropológicos, Porto Alegre, ano 20, n. 41, p. 433-436, jan./jun. 2014 
Nos idos de 1980, consolidam-se os programas de pós-graduação em antropologia e ciências sociais, ao mesmo tempo em que há uma politização de temas da antropologia e a intensificação de pesquisas no meio urbano. Nesse contexto a linha de pesquisa de Gilberto Velho, assim como de seus orientandos, é citada pela síntese que promove entre diferentes tradições. O texto “Observando o familiar”, de Gilberto Velho (1978), é um clássico na discussão sobre o estranhamento do familiar e os desafios da alteridade próxima. São comentados, entre tantos outros pontos relevantes, os desdobramentos do impacto dos estudos antropológicos de Gilberto Velho, ao lado de outras questões tais como a antropologia das sociedades complexas e dos grupos urbanos e a reverberação do ideário individualista na pesquisa etnográfica na cidade.

No capítulo 2, "Etnografia da e na cidade, saberes e práticas”, as autoras contribuem com uma apresentação da perspectiva etnográfica, seu ensino e sua aprendizagem tendo em vista ser ela o diferencial da construção epistemológica no campo antropológico. Esse texto, embora inicialmente direcionado à graduação em antropologia, representa uma contribuição para seu uso em outras áreas de conhecimento, já que esse legado da antropologia é apropriado por outros campos do saber nem sempre de forma feliz. Assim, são discutidos os meandros da elaboração de um projeto antropológico, procedimentos na observação direta, a fabricação do objeto de pesquisa através de questões que incidem sobre a construção da realidade social e as interações durante o trabalho de campo que, como se sabe, é o emblema do fazer antropológico. Não nos esqueçamos, entretanto, que não existem fórmulas prontas, sendo fundamental a leitura e intimidade com as boas etnografias. Vale a pena, ainda, frisar os usos das novas tecnologias eletrônicas e digitais na produção de outras escritas.

O capítulo 3, como expressa o título, é dedicado a "Narrativas imagéticas”. Esse capítulo reúne trabalhos de discípulos das autoras, no âmbito do mestrado e do doutorado. São narrativas visuais que falam de bairros da cidade e de suas transformações, sempre acompanhados de uma sinopse. As ruas, as casas e seus interiores assim como as sociabilidades de seus habitantes são linguagem e contam histórias.

Nos capítulos 4 e 5, respectivamente intitulados “"A cidade com qualidade’: estudo de memória e esquecimento sobre medo e crise na cidade de Porto Alegre" e "Cidade sitiada, o medo como intriga”, as antropólogas tratam das mudanças sociais e da vivência de insegurança e medo vividas no cotidiano.

Horizontes Antropológicos, Porto Alegre, ano 20, n. 41, p. 433-436, jan./jun. 2014 
Nesses capítulos o leitor pode aproximar-se da chamada "cultura do medo". Fotos e episódios narram estratégias usadas para proteção contra a violência, revelando o que as autoras chamam, com muita acuidade, de "estética de segurança” ou "estética do medo" (p. 109).

Nos capítulos 6 e 7, respectivamente intitulados "As variações 'paisageiras' na cidade e os jogos de memória” e "A fabricação das paisagens, os jogos de memória e os trabalhos da imaginação criadora”, as pesquisadoras discutem densamente a formação da categoria paisagem como conceito, assim como a sua operacionalização em projetos que englobam tanto as etnografias escritas como, ainda, a realização de vídeos e coleções fotográficas. São textos complexos tecidos com as teias da memória, da política e da imagem.

No capítulo 8, "A irracionalidade do belo e a estética urbana no Brasil”, Ana Luiza Carvalho da Rocha e Cornelia Eckert encerram o livro com uma reflexão que tem na formação da cidade de Porto Alegre um manancial de símbolos, memórias e histórias para pensar tanto a sua própria estética urbana como, num voo mais abrangente, refletir sobre a estética urbana brasileira.

\section{Referências}

VELHO, G. Observando o familiar. In: NUNES, E. de O. (Org.). A aventura sociológica: objetividade, paixão, improviso e método na pesquisa social. Rio de Janeiro: Zahar, 1978. p. 36-47.

VELHO, G. Memória, identidade e projeto In: VELHO, G. Projeto $e$ metamorfose: antropologia das sociedades complexas. Rio de Janeiro: Jorge Zahar Editor, 1994. p. 97-113. 